\title{
Evaluation of body posture in nursing students
}

\author{
Avaliação da postura corporal em estudantes de enfermagem \\ Evaluación de la postura corporal en estudiantes de enfermería
}

\author{
Marília Fernandes Andrade ${ }^{1}$, Érika de Cássia Lopes Chaves ${ }^{1}$ Michele Rita Oliveira Miguel ${ }^{1}$, Talita Prado Simão², Denismar \\ Alves Nogueira ${ }^{3}$, Denise Hollanda lunes ${ }^{1}$
}

How to cite this article:

Andrade MF, Chaves ECL, Miguel MRO, Simão TP, Nogueira DA, lunes DH. Evaluation of body posture in nursing students. Rev Esc Enferm USP. 2017;51:e03241. DOI: http://dx.doi.org/10.1590/S1980-220X2016027303241

\author{
${ }^{1}$ Universidade Federal de Alfenas, Escola \\ de Enfermagem, Alfenas, MG, Brazil. \\ ${ }^{2}$ Universidade de São Paulo, Escola \\ de Enfermagem de Ribeirão Preto, \\ Ribeirão Preto, SP, Brazil. \\ ${ }^{3}$ Universidade Federal de Alfenas, Instituto \\ de Ciências Exatas, Alfenas, MG, Brazil.
}

\begin{abstract}
Objective: To investigate the body posture of nursing students before and after clinical practice. Method: The study was developed in two stages. Initially the body posture of students of the 2nd, 4th, 6th, and 8th periods were assessed through photogrammetry. All images were analyzed in a random and masked manner with CorporisPro ${ }^{\circledR}$ 3.1.3 software. Three evaluations were performed for each angle and then the mean value was calculated. Two years later, when the 4th period students had developed their clinical internships, their body posture was again evaluated. Results: The total sample consisted of 112 students. Comparison of their posture with the normality pattern showed that all the angles presented significant differences $(p<0.00)$, except for the angle of the Thales triangle. Reassessment of these students evidenced significant differences in the angles of the acromioclavicular joint $(\mathrm{p}=0.03)$, knee flexion $(\mathrm{p}<0.00)$ and in the tibiotarsal angle $(p<0.00)$. Conclusion: All the students presented alterations when compared to the normality values. The segments that presented significant differences between before and after practice were the acromioclavicular angle, knee flexion, and tibiotarsal angle; the latter two were in the rolling position.
\end{abstract}

\section{DESCRIPTORS}

Students, Nursing; Posture, Photogrammetry; Occupational Health.
Corresponding author:

Denise Hollanda lunes

Av. Jovino Fernandes Sales, 2600 - Santa Clara

CEP 37130-000 - Alfenas, MG, Brazil

deniseiunes@unifal-mg.edu.br
Received: 07/15/2016

Approved: 03/21/2017 


\section{INTRODUCTION}

There is close relationship between ergonomic risk factors and postural habits adopted at work and injuries and musculoskeletal pain ${ }^{(1)}$. Posture in the workplace can be understood as the way in which the parties of the body are guided in work environments during the performance of work activities, considering the characteristics of professionals ${ }^{(2)}$. The achievement of balance between body structures, such as the spine and limbs, in order to prevent pathologies during daily and work activities, represents a major challenge.

Health professionals, particularly those who have close relationships with patients, present a high incidence of stress and pain complaints ${ }^{(3-4)}$. In this scenario, it is possible to mention nursing professionals, since they tend to experience body overload during some of the tasks they perform in their daily routine, such as moving, repositioning, and transferring patients. These activities demand a certain level of physical effort, and involve movements that are often performed with inappropriate postures ${ }^{(4-5)}$.

Poor postural habits acquired in the performance of work activities may trigger body changes that are reflected by musculoskeletal pain. According to results of studies conducted in recent decades, nurses present low back pain as their major complaint ${ }^{(6-7)}$, as well as pain in the cervical region, wrists, shoulders, and knees $^{(8-9)}$. Postural deviations have been shown to be mainly related to different types of pain in the lumbar region ${ }^{(10)}$. In addition, some studies have shown an association between postural imbalances and musculoskeletal disorders that generate rheumatic diseases such as osteoarthritis of the knee, ankle instability, cervical tension and low back pain ${ }^{(11-12)}$.

Other studies have shown increased risk of musculoskeletal diseases in the cervical, lumbar, and upper limb regions in a number of professionals who present inappropriate posture at work, including nurses ${ }^{(13-18)}$. For this reason, there is a need for studies focusing on postural disorders to investigate their prevalence, and to support primary and secondary prevention of musculoskeletal pathologies in nursing professionals.

Previous studies have shown the importance of assessing the posture of these professionals as early as possible, that is, since their insertion into clinical practice during undergraduate studies. Moreover, it is important to observe the modifiable aspects of posture in order to enable the development of ergonomic strategies that will allow the prevention of musculoskeletal disorders, a frequent problem in this population ${ }^{(13-14)}$. The literature presents several tools that allow the assessment of body posture in different planes (frontal, sagittal and transverse), including quantitative methods in which the images are processed and analyzed through the use of a software, ensuring standardized, easy-to-use methods that facilitate the verification of results and clinical analyses ${ }^{(19-21)}$.

Among the instruments mentioned, photogrammetry is an effective technique that allows easy interpretation. It is already in use for posture recording, and a number of professionals have easy access to its technological equipment ${ }^{(22)}$.

In view of the above, the present study aimed at investigating the posture of nursing students before and after clinical practice.

\section{METHOD}

Descriptive, cross-sectional ( $1^{\text {st }}$ stage) and longitudinal ( $2^{\text {nd }}$ stage) study conducted from August 2011 to March 2014.

The study population consisted of 160 nursing students at the Universidade Federal de Alfenas (UNIFAL-MG). The sample included all the students of the nursing course enrolled in the undergraduate program in the academic years 2011/2012 and 2013/2014 who were 18 years old or more and agreed to participate in the study. The study was developed in two stages: In the first stage 112 nursing students $\left(2^{\text {nd }}, 4^{\text {th }}, 6^{\text {th }}\right.$, and $8^{\text {th }}$ periods) who had been selected based on their interest in participating in the study had their body posture photographed. In the second stage, at the end of the 2-year period, 20 students who had participated in the first stage, finished their clinical practice, and expressed their interest in being reassessed were photographed again. It is important to mention that in the first stage these students were still not carrying out internship activities; they were only involved in laboratory practice.

The invitations to participate and scheduling of the postural assessments were carried out by telephone. All the students signed free and informed consent forms. This study was approved by the Committee of Ethics in Research with Human Subjects in accordance with Resolution 196/96 of the National Health Council under protocol number $032 / 2011$.

Initially, personal and anthropometric data were collected. The postural evaluations were conducted by photographic recording in a room that provided privacy and adequate lighting. The students wore bathing suits with no jewelry or other accessories. In the orthostatic position, the following anatomical points were marked with self-adhesive labels: (a) the occipital protuberance; (b) the spinous processes of the $\mathrm{C}_{4}, \mathrm{C}_{7}, \mathrm{~T}_{8}, \mathrm{~T}_{12}, \mathrm{~L}_{3}, \mathrm{~L}_{5}$ vertebrae; (c) the acromioclavicular joint (bilaterally); (d) the sternoclavicular joint (bilaterally); (e) the inferior angle of the scapula (bilaterally); (f) the anterior superior (ASIS), posterior superior, and posterior inferior iliac spines, bilaterally; (g) the greater trochanter; (h) the tuberosity of the tibia; (i) the head of the fibula; (j) the lateral malleolus; and (q) the tuberosity of the distal diaphysis of the $5^{\text {th }}$ metatarsus.

Photographic recordings were made for the frontalanterior, frontal posterior and sagittal planes. A 7.2 MP $\mathrm{SONY}^{\oplus}$ Cyber-Shot digital camera was positioned in a previously marked location on a tripod leveled 1 meter parallel to the floor and at a standard distance of 2.4 meters from the participants ${ }^{(22)}$ (Figure 1). The zoom function of the camera was disabled. A rectangular marker in ethylene vinyl acetate (EVA) was used to maintain the position of the participants; it kept the heel of the volunteer $0.15 \mathrm{~m}$ away from the wall, with the dimensions: $0.15 \mathrm{~m}$ wide, $0.60 \mathrm{~m}$ 
long, and $0.05 \mathrm{~m}$ thick. Another $0.075 \mathrm{~m}$ wide EVA device was placed between the feet of the participants. During the recordings, the only verbal command was: focus your eyes on the horizon, as any other command would have changed the body consciousness of the students, as a result, the presented posture would not have been the actual posture.

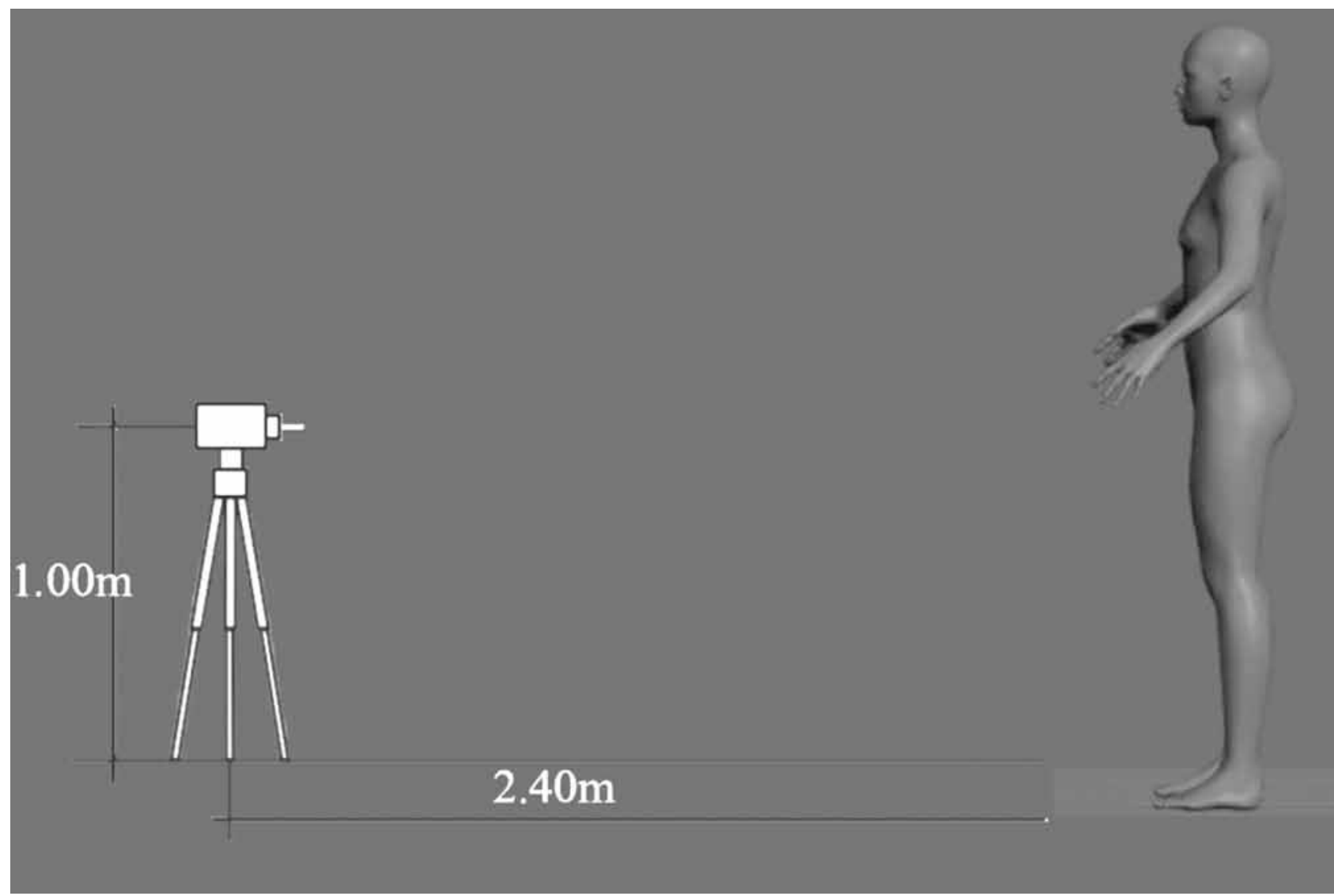

Figure 1 - Positioning of the volunteer and the equipment to perform the digital photograph. Source: Authors of the research.

The marked points enabled measurement of the angles based on the markers attached to the skin: some were white $\mathrm{PIMACO}^{\circledR}$ self-adhesive labels $0.9 \mathrm{~mm}$ in diameter; others were $0.6 \mathrm{~mm}$ plastic rods that were needed to mark the points of the occipital protuberance, spine, and pelvis.

In the frontal-anterior and frontal-posterior planes, the marked angles were: in the frontal-anterior plane - sternoclavicular (EC); acromioclavicular (AC); anterior-superior iliac spines (ASIS); Thales' triangle $(\Delta \mathrm{T})$ (Figure 2A); knee angulation (AJ) (Figure 2D); in the frontal-posterior plane - inferior angles of the scapula (IE); posterior-superior iliac spines (Figure 2B).

Symmetry was determined by the union of pre-established lines connecting the anatomical points marked on the right and their corresponding points on the left with the straight line parallel to the ground given by the analysis software. Based on the angular values found; those presenting zero value were considered symmetric, and those presenting values greater than or equal to 0.1 degree were considered asymmetric ${ }^{(22)}$.

All the angles of the anterior and posterior frontal planes assessed symmetry, but the angle $\Delta \mathrm{T}$, formed by the intersection of the line passing through the medial border of the upper limb with the line passing adjacent to the waist, was not marked to assess symmetry (Figure 2A).

In the analysis of posture in the sagittal plane, the angles are denominated: protrusion of the head (PC); cervical lordosis (LC); thoracic kyphosis (CT); lumbar lordosis (LL); pelvic bascule (BP); knee flexion (FJ); and tibiotarsal angle (ATT) (Figure 2C).

Protrusion of the head was assessed by measurement of the intersection of a line connecting the points of the tragus of the ear to the spinous process of $\mathrm{C}_{7}$ and a line parallel to the ground. The intersection of a line from the occipital protuberance passing through the spinous processes of $\mathrm{C}_{4}$ and $\mathrm{C}_{7}$ was used to analyze cervical lordosis. Similarly, the union of the points of the spinous processes of $\mathrm{C}_{7}, \mathrm{~T}_{7}$ and $\mathrm{T}_{12}$ was the measure of thoracic kyphosis, and the spinous processes of $\mathrm{T}_{12}, \mathrm{~L}_{3}$ and $\mathrm{L}_{5}$ formed the angle of lumbar lordosis.

The BP angle is formed by the intersection of a line connecting the ASIS, EIPI with a line parallel to the ground, considered normal when its value was zero ${ }^{(22)}$. When the EIPS is lower, it forms a negative angle, considered pelvic retroversion, and when the EIAS is lower it forms a positive angle, considered pelvic anteversion. There are 
some exceptions, such as the angle $\Delta \mathrm{T}$ (Figure $2 \mathrm{~A}$ ), which is classified as symmetrical or asymmetrical by comparing the qualitative measure for the right and left sides. The angles of the sagittal plane, being PC, LC, CT, LL (Figure 2C), do not present standard values of normality in the literature ${ }^{(22)}$.
However, the present study considered angular measures: in the angle PC, the lower the value the higher the head protrusion; in the LC and LL, the lower the value of the angle the greater the cervical and lumbar curvature; and in the CT, the higher the angle the more stressed the thoracic kyphosis.

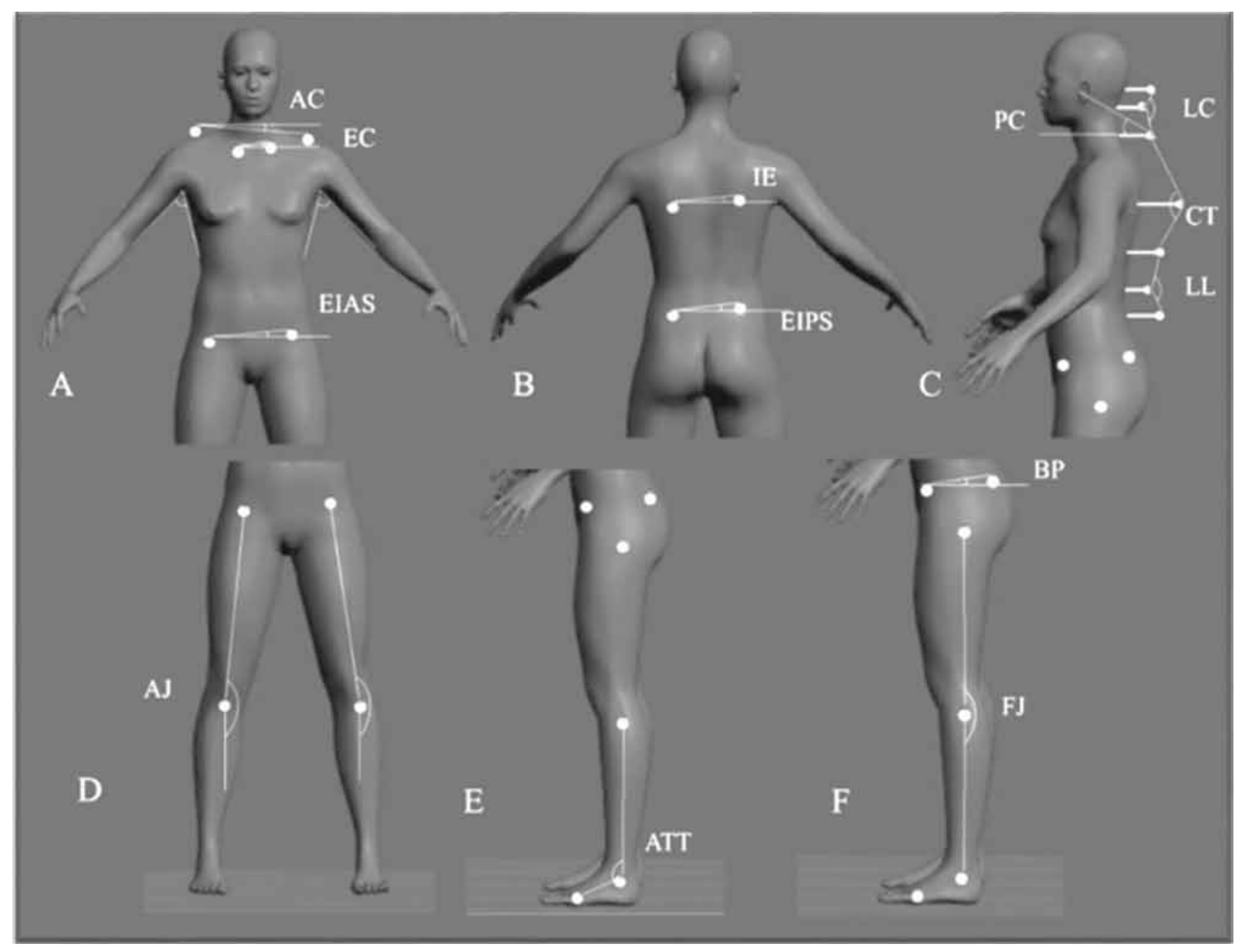

Figure 2 - Angles analyzed in the anterior (2A), posterior (2B), and sagittal (2C) frontal planes and angles assessed in the lower limbs (2D, 2E and 2F). Source: Authors of the research.

The knee flexion angle (FJ) (Figure 2F) and tibiotarsal angle (ATT) (Figure 2E) were also analyzed, presenting normality patterns and being classified as normal with measures equivalent to $180^{\circ}$ and $90^{\circ}$,respectively. Moreover, these angles were also assessed in the rolling of the trunk at the moment of the photograph (FJ rol. and ATT rol.), and were analyzed through the confluence of anatomical points in the FJ, greater trochanter, head of the fibula, and lateral malleolus. The points of the head of the fibula, lateral malleolus, and tuberosity of the distal diaphysis of the $5^{\text {th }}$ metatarsus were used for the ATT.

All the digitalized images were stored for subsequent analysis with CorporisPro ${ }^{\circledR} 3.1 .3$ software, which allows lines to be digitally traced and presents angular values in degrees. The photos were randomized and the researcher was blinded for the group in which the student was inserted. Each angle was analyzed three times in order to calculate a mean value, always repeating the procedure of tracing the lines and writing down the values.

The collected quantitative data were grouped in a database using Microsoft Excel (2007). Data normality was investigated using the Kolmogorov-Smirnov test. The t-test was used for the comparative analyses between the obtained values and the normality values ${ }^{(22)}$. The Wilcoxon test and paired t-test were used to compare the assessments and reassessments of the same individuals in accordance with the normalization of the variable. The Statistical Package for the Social Sciences (SPSS) version 17.0 was used, and the significance level was set at $5 \%$.

\section{RESULTS}

The total sample consisted of 112 students with a mean age of 21.6 ( \pm 2.6$)$ years and body mass index (BMI) of $22.7( \pm 3.8)$ $\mathrm{Kg} / \mathrm{m}^{2}$. The results of the comparison with the normality 
pattern showed that in general the students presented significant postural alterations (Table 1). The values of all the analyzed angles presented a deviation from the normality pattern, except for the angle of the difference between the Thales' triangle on the right and left sides $(\Delta \mathrm{Td}-\Delta \mathrm{Te}) \quad(\mathrm{p}=0.34)$.

The students were reassessed a second time after two years of practice activities (practical classes and internship).
No significant differences were observed in most of the analyzed angles of the reassessed students.

The acromioclavicular joint (AC) was the segment with postural differences; it presented greater asymmetry before than after clinical practice $(\mathrm{p}=0.03)$. The knee flexion $(\mathrm{FJ})$ and tibiotarsal (ATT) angles also presented significant differences at the time of rolling the trunk.

Table 1 - Comparison of the angles analyzed in all the nursing students with the normality pattern - Alfenas, Minas Gerais, Brazil, 2011/2012.

\begin{tabular}{|c|c|c|c|c|}
\hline Plane & Angle & Mean $(95 \% \mathrm{Cl})\left({ }^{\circ}\right)$ & Normality $\left({ }^{\circ}\right)$ & $p$ value \\
\hline \multirow{5}{*}{$\begin{array}{l}\text { Frontal } \\
\text { Anterior }\end{array}$} & $\mathrm{EC}$ & $4.87(4.86$ to 7.20$)$ & 0 & $<0.00^{*}$ \\
\hline & $\mathrm{AC}$ & $6.01(4.78$ to 7.25$)$ & 0 & $<0.00^{*}$ \\
\hline & EIAS & $2.52(2.05$ to 2.98$)$ & 0 & $<0.00^{*}$ \\
\hline & $\neq \Delta \mathrm{Td}$ e $\Delta \mathrm{Te}$ & $0.44(-0.48$ to 1.35$)$ & 0 & 0.34 \\
\hline & AJ & $181.12(180.5$ to 181.75$)$ & 170 & $<0.00$ \\
\hline \multirow{2}{*}{$\begin{array}{l}\text { Frontal } \\
\text { Posterior }\end{array}$} & IE & 2.42 (1.99 to 2.85$)$ & 0 & $<0.00^{*}$ \\
\hline & EIPS & $2.97(2.29$ to 3.65$)$ & 0 & $<0.00^{*}$ \\
\hline \multirow{5}{*}{ Sagittal } & $\mathrm{BP}$ & $5.38(4.55$ to 6.21$)$ & 0 & $<0.00^{*}$ \\
\hline & FJ & $184.52(183.27$ to 185.78$)$ & 180 & $<0.00^{*}$ \\
\hline & ATT & $145.71(136.65$ to 154.78$)$ & 90 & $<0.00^{*}$ \\
\hline & FJ ROL. & $185.72(184.13$ to 187.31$)$ & 180 & $<0.00^{*}$ \\
\hline & ATT ROL. & $185.72 \pm(184.3$ to 187.31$)$ & 90 & $<0.00^{*}$ \\
\hline
\end{tabular}

CI: confidence interval / $\mathrm{t}$-test $/{ }^{*} \mathrm{p}<0.005$.

Note: $(n=112)$

Table 2 - Postural reassessment of students at the $4^{\text {th }}$ period and after the $9^{\text {th }}$ period - Alfenas, Minas Gerais, Brazil, $2011 / 2012$ and 2013/2014.

\begin{tabular}{|c|c|c|c|c|}
\hline Plane & Angle & Before Mean $\left(95 \%\right.$ IC) $\left(^{\circ}\right)$ & After Mean $\left(95 \%\right.$ of IC) $\left({ }^{\circ}\right)$ & $p$ value \\
\hline \multirow{5}{*}{$\begin{array}{l}\text { Frontal } \\
\text { Anterior }\end{array}$} & $\mathrm{EC}^{1}$ & $3.38(1.90-4.85)$ & $1.38(0.86-1.90)$ & 0.06 \\
\hline & $\mathrm{AC}^{1}$ & $2.41(1.48-3.33)$ & $1.33(0.87-1.79)$ & $0.03 *$ \\
\hline & $\mathrm{EIAS}^{2}$ & $1.80(1.29-2.50)$ & $1.63(1.09-2.17)$ & 0.58 \\
\hline & $\neq \Delta \mathrm{Td}$ e $\Delta \mathrm{Te}^{1}$ & $6.77(3.61-9.92)$ & $5.73(3.07-8.39)$ & 0.72 \\
\hline & $A J^{2}$ & $179.21(175.40-182.94)$ & $181.23(176.88-184.71)$ & 0.45 \\
\hline \multirow{2}{*}{$\begin{array}{l}\text { Frontal } \\
\text { Posterior }\end{array}$} & $\mathrm{IE}^{2}$ & $2.19(1.43-2.96)$ & $1.70(1.25-2.14)$ & 0.32 \\
\hline & EIPS $^{1}$ & $1.91(1.17-2.66)$ & $1.40(0.90-1.89)$ & 0.18 \\
\hline \multirow{9}{*}{ Sagittal } & $\mathrm{BP}^{1}$ & $1.55(0.93-2.18)$ & $1.08(0.62-1.54)$ & 0.23 \\
\hline & $F J^{2}$ & $183.94(181.56-186.31)$ & $185.91(184.57-187.24)$ & 0.12 \\
\hline & $\mathrm{ATT}^{1}$ & $120.57(117.45-123.70)$ & $121.32(113.20-129.44)$ & 0.34 \\
\hline & FJ ROL. ${ }^{2}$ & $175.30(179.45-187.07)$ & $174.82(173.81-177.84)$ & $<0.001^{*}$ \\
\hline & ATT ROL. ${ }^{2}$ & 131.49 (129.03-133.95) & $126.94(124.70-129.18)$ & $<0.001^{*}$ \\
\hline & $\mathrm{PC}^{2}$ & $49.49(47.73-51.25)$ & $49.64(47.51-51.77)$ & 0.80 \\
\hline & $\mathrm{LC}^{2}$ & $135.71(132.20-139.21)$ & $134.10(130.18-138.03)$ & 0.46 \\
\hline & $\mathrm{CT}^{2}$ & $205.99(203.22-208.75)$ & $207.15(203.72-210.57)$ & 0.34 \\
\hline & $\mathrm{LL}^{2}$ & $157.32(152.78-161.85)$ & $156.71(151.50-161.53)$ & 0.82 \\
\hline
\end{tabular}

CI: confidence interval/ Wilcoxon test ${ }^{1}$ and $\mathrm{t}$-test ${ }^{2} /{ }^{*} \mathrm{p}<0.005$.

Note: $(n=20)$.

\section{DISCUSSION}

Postural alterations may cause damage to the health and general well-being of individuals, significantly impacting their work performance. In recent years, the importance of postural education has been verified as a means to reduce high prevalence of lumbar pain and postural alterations, which generate several types of damage, especially in the spine ${ }^{(23)}$.

Poor posture in the workplace may be related to higher risk of musculoskeletal diseases in different regions of the body for professionals ${ }^{(11,14,17)}$. The present study was focused on nurses, since they experience significant postural overload due to their adaptation to the activities performed in their work routines. Considering their exposure to poor posture habits and occupational activities that present both physical and emotional impact, these situations contribute to the development of chronic postural and musculoskeletal disorders in nursing professionals ${ }^{(24-25)}$. The pain and discomfort caused by musculoskeletal diseases, particularly low back pain, may affect the work of nurses, changing their routines and performance, modifying the work environment, and even leading to abandonment of the profession due to overwork ${ }^{(26)}$. 
Extensive clinical practice workloads encountered after academic training may lead to significant damage to nursing students who may already present imbalanced body postures. Therefore, it is essential to prevent postural injuries, because nursing is a profession characterized by prolonged static, asymmetrical, twisted postures associated with activities such as support for surgeries and instrumentation, or even movement of patients ${ }^{(27)}$.

Quantitative analysis of the body posture of nursing students showed that most angles presented deviation from normality ${ }^{(22)}$, indicating that they presented significant alterations. It is important to mention that there is no normality pattern for the angular values of PC, LC, CT, and LL, but it is possible to confirm the mean angulation values presented by the students.

The same analysis showed the occurrence of major deviations in the acromioclavicular (AC) and sternoclavicular (EC) angles, all in the region of the shoulders and upper limbs, considering those of the frontal plane as symmetric angles. The values of these angles differed from the normality values ${ }^{(22)}$, which would be the angular symmetry. A symmetric segment indicates muscle balance and bone structures in normal anatomic conditions, without postural deviations, especially in the scapular and pelvic girdles. This balance represents a challenge in classroom routines, where students acquire compensatory postural habits in response to several factors, such as remaining in a same posture for long periods ${ }^{(7)}$.

The comparison of postures of individuals before and after clinical practice found no significant differences in most analyzed angles. Regarding segment with significant difference, the study emphasizes the acromioclavicular joint $(\mathrm{AC})$, which presented greater asymmetry before than after practice $(\mathrm{p}=0.03)$. An explanation for this finding may be that the students may already have presented postural alterations at the beginning of the nursing course.

There is previous evidence of overload of the upper limbs in these professionals ${ }^{(27)}$; pain in the neck, shoulders, hands, and lumbar area may be associated with movements with the upper limbs suspended and high work demands. For the cervical region, some situations tend to lead to increased muscle tension, such as those requiring a lot of attention and visual activity, including reading of medication labels and intravenous feeding of patients.

Constant attention, maintenance of orthostatic positions during work, and emotional tension imposed on these professionals are evident ${ }^{(16)}$, and this is reflected in their bodies and mental health, as well as in their posture.

The maintenance of orthostatic posture or bipodal support involves weight discharge that determines the position of the pelvis and the spine, provides a support base, and supports postural balance and the distribution of plantar pressure $^{(18)}$. This already-established body structure may be affected by the postural "habits" associated with the performed activities, leading to musculoskeletal compensation.

The adaptations generated by muscle compensation may be fully associated with the flexibility that emerges as a capacity that, despite the lack of understanding of the mechanism of its contribution to preventing injuries, has been shown to be a relevant risk factor for degenerative pathologies such as low back pain ${ }^{(7)}$. This suggests a possible association of posterior muscle shortening with professions in which individuals remain sitting or in the orthostatic position most of the time. Students generally spend much of the day sitting in the classroom, a risk factor for this alteration. It was observed that the prevalence of this posture in nursing students is reversed when they begin clinical practice in internships.

At this stage students spend much of the day in the orthostatic position. The shortening of angles, namely the knee flexion (FJ) and tibiotarsal (ATT) angles, showed significant differences at the time of trunk rolling. Therefore, after the clinical practice, the data presented by the FJ rol. angle showed a higher level of shortening, the furthest from the angle value of normality. The opposite was observed in the ATT rol.; the values suggested that in this segment there was a lower level of shortening after the clinical practice; the value was the closest to normality.

A limitation of the present study was the difficulty of getting the students to participate, particularly at the time of the reassessment, because they were experiencing curricular overload. The workload of the internships and the development of their final course papers led to a significant loss from the sample of students who were unavailable or showed no interest in the reassessment at that time. In addition, some of them were no longer attending the nursing course in the institution.

However, the relevance of the study is related to health promotion and prevention for nursing students and professionals. It is important to emphasize the scarcity of literature approaching the cause of the disorders, pain, and chronic conditions that affect these professionals during their professional development.

\section{CONCLUSION}

All the students presented alterations in comparison to normality values. The comparison of these same individuals before and after clinical practice showed no significant differences in most analyzed angles. The segments that did present significant differences before and after practice were the acromioclavicular, knee flexion, and tibiotarsal angles; the latter two in the rolling position. Further longitudinal studies with longer follow-up periods are necessary to answer the question whether professional practice really leads to changes in body posture. 
imagens foram analisadas, de maneira aleatória e mascarada, por meio do software CorporisPro ${ }^{\circledR}$ 3.1.3. Foram realizadas três avaliações para cada ângulo e calculada a média. Dois anos depois, quando os estudantes do 4 o período desenvolveram os estágios clínicos, foram novamente avaliados quanto à postura corporal. Resultados: A amostra total foi composta por 112 estudantes. Comparando-se os estudantes com o padrão de normalidade, todos os ângulos apresentaram diferença significativa $(p<0,00)$, com exceção do ângulo triângulo de Tales. Reavaliando os mesmos estudantes, houve diferença significativa nos ângulos da articulação acromioclavicular $(\mathrm{p}=0,03)$, da flexão de joelhos $(\mathrm{p}<0,00)$ e no ângulo tibiotársico $(\mathrm{p}<0,00)$. Conclusão: Todos os estudantes apresentaram alterações, comparadas aos valores de normalidade. Os segmentos com diferença significativa, comparando-se antes e após a prática, foram o ângulo acromioclavicular, flexo de joelho e ângulo tibiotársico, sendo os dois últimos na posição de rolamento.

\section{DESCRITORES}

Estudantes de Enfermagem; Postura; Fotogrametria; Saúde do Trabalhador.

\section{RESUMEN}

Objetivo: Investigar la postura de los estudiantes de enfermería antes y después de la práctica clínica. Método: El estudio fue desarrollado en dos etapas, inicialmente los estudiantes $\left(2^{\circ}, 4^{\circ}, 6^{\circ}\right.$ y $8^{\circ}$ períodos $)$ tuvieron su postura corporal evaluada por medio de la fotogrametría. Todas las imágenes fueron analizadas, de manera aleatoria y enmascarada, mediante el software CorporisPro ${ }^{\circledR}$ 3.1.3. Se llevaron a cabo tres evaluaciones para cada ángulo y se calculó el promedio. Tras dos años, cuando los estudiantes del $4^{\circ}$ período desarrollaron las prácticas clínicas, fueron nuevamente evaluados en cuanto a la postura corporal. Resultados: La muestra total estuvo compuesta de 112 estudiantes. Comparándose los estudiantes con el estándar de normalidad, todos los ángulos presentaron diferencia significativa $(p<0,00)$, excepto por el ángulo triángulo de Tales. Reevaluando los mismos estudiantes, hubo diferencia significativa en los ángulos de la articulación acromioclavicular $(\mathrm{p}=0,03)$, de la flexión de rodillas $(\mathrm{p}<0,00)$ y ángulo tibiotársico $(\mathrm{p}<0,00)$. Conclusión: Todos los estudiantes presentaron alteraciones, comparadas con los valores de normalidad. Los segmentos con diferencia significativa, comparándose antes y después de la práctica, fueron el ángulo acromioclavicular, flexo de rodilla y ángulo tibiotársico, siendo los dos últimos en la posición de rodamiento.

\section{DESCRIPTORES}

Estudiantes de Enfermería; Postura, Fotogrametría; Salud Laboral.

\section{REFERENCES}

1. Abdollahzade F, Mohammadi F, Dianat I, Asghari E, Asghari-Jafarabadi M, Sokhanvar Z. Working posture and its predictors in hospital operating room nurses. Health Promot Perspect. 2016;6(1):17-22.

2. Zein RM, Halim I, Azis NA, Saptari A, Kamart SR. A survey on working postures among Malaysian industrial workers. Proc Manf. 2015;2:450-9.

3. Bonzini M, Bertu L, Veronesi G, Ferrario MM, Conti M, Coggon D, et al. Is musculoskeletal pain a consequence or a cause of occupational stress? A longitudinal study. Arch Occup Environ Health. 2015;88(5):607-12.

4. Alperovitch-Najenson D, Treger I, Kalichman L. Physical therapists versus nurses in a rehabilitation hospital: comparing prevalence of work related musculoskeletal complaints and working conditions. Arch Environ Occup Health. 2015;69(1):33-9.

5. Nodooshan HS, Choobineh A, Razeghi M, Khales GTSN. A survey of patient handling between bed and stretcherand associated problems in hospital environments. J Ergon. 2016;3(4):74-81.

6. Babadi ME, Nazari F, Safari R, Abdoli S. The effect of reflexology on pain perception aspects in nurses with chronic low back pain in Isfahan. Iran J Nurs Midwifery Res. 2016;21(5):487-92.

7. Petersen RS, Marziale MHP. Low back pain characterized by muscle resistance and occupational factors associated with nursing. Rev Latino Am Enfermagem. 2014;22(3):386-93.

8. Galinsky T, Hudock S, Streit J. Addressing the need for research on bariatric patient handling. Rehabil Nurs. 2015;35(6):242-47.

9. Choi SD, Brings K. Work-related musculoskeletal risks associated with nurses and nursing assistants handling overweight and obese patients: a literature review. Work. 2015;53(2):439-48.

10. Truszczyńska A, Dobrzyńska M, Trzaskoma Z, Drzał-Grabiec J, Tarnowski A. Assessment of postural stability in patients with lumbar spine chronic disc disease. Acta Bioeng Biomech. 2016;18(4):71-7.

11. Bernal D, Campos-Serna J, Tobias A, Vargar-Prada S, Bernavides FG, Serra C. Work-related psychosocial risk factors and musculoskeletal disorders in hospital nurses and nursing aides: a systematic review and meta-analysis. Int J Nurs Stud. 2015;52(2):635-48.

12. Davis KG, Kotowski SE. Prevalence of musculoskeletal disorders for nurses in hospitals, long-term care facilities, and home health care: a comprehensive review. Hum Factors. 2015;57(5):754-92.

13. Akter S, Maruf MZ, Chowdhury SK. Prevalence of musculoskeletal symptoms and associated factors: a cross-sectional study of metal workers in Bangladesh. Work. 2015;50(3):363-70.

14. Harari G, Green MS, Zelber-Sagi S. Combined association of occupational and leisure-time physical activity with all-cause and coronary heart disease mortality among a cohort of men followed-up for 22 years. Occup Environ Med. 2015;72(9):617-24.

15. Rodrigues EP, Rodrigues US, Oliveira LMM, Laudano RCS, Nascimento Sobrinho CL. Prevalência de transtornos mentais comuns em trabalhadores de enfermagem em um hospital da Bahia. Rev Bras Enferm. 2014;67(2):296-301.

16. Schall MCJr, Fethke NB, Chen H. Working postures and physical activity among registered nurses. Appl Ergon. 2016;54:243-50.

17. Dianat I, Kord M, Yahyazade P, Karimi MA, Stedmon AW. Association of individual and work-related risk factors with musculoskeletal symptoms among Iranian sewing machine operators. Appl Ergon. 2015;51:180-8. 
18. Schall Jr MC, Fethke NB, Chen H. Working postures and physical activity among registered nurses. Appl Ergon. 2016;54:243-50.

19. Aroeira RM, de Las Casas EB, Pertence AE, Greco M, Tavares JM. Non-invasive methods of computer vision in the posture evaluation of adolescent idiopathic scoliosis. J Bodyw Mov Ther. 2016;20(4):832-43.

20. Furlanetto TS, Sedrez JA, Candotti CT, Loss JF. Photogrammetry as a tool for the postural evaluation of the spine: a systematic review. World J Orthop. 2016;7(2):136-48.

21. Ruivo RM, Pezarat-Correia P, Carita AI. Intrarater and interrater reliability of photographic measurement of upper-body standing posture of adolescents. J Manipulative Physiol Ther. 2015;38(1):74-80.

22. Iunes DH, Elias IF, Carvalho LC, Dionísio VC. Postural adjustments in young ballet dancers compared to age matched controls. Phys Ther Sport. 2016;17:51-7.

23. Sedrez JA, Rosa MIZ, Noll M, Medeiros FS, Candotti CT. Risk factors associated with structural postural changes in the spinal column of children and adolescents. Rev Paul Pediatr. 2015;33(1):72-81.

24. Freimann T, Pääsuke M, Merisalu E. Work-related psychosocial factors and mental health problems associated with musculoskeletal pain in nurses: a cross-sectional study. Pain Res Manag. 2016;ID9361016. DOI: http://dx.doi.org/10.1155/2016/9361016

25. Harari G, Green MS, Zelber-Sagi S. Combined association of occupational and leisure-time physical activity with all-cause and coronary heart disease mortality among a cohort of men followed-up for 22 years. Occup Environ Med. 2015;72(9):617-24.

26. Harcombe H, Herbison GP, McBride D, Derrett S. Musculoskeletal disorders among nurses compared with two other occupational groups. Occup Med (Lond). 2014;64(8):601-07.

27. Arvidsson I, Simonsen JG, Dahlqvist C, Axmon A, Karlson B, Björk J, et al. Cross-sectional associations between occupational factors and musculoskeletal pain in women teachers, nurses and sonographers. BMC Musculoskelet Disord. 2016;17:35-50. 